\title{
PENGARUH TERAPI AKTIVITAS KELOMPOK PENINGKATAN HARGA DIRI TERHADAP HARGA DIRI KLIEN MENARIK DIRI DI RUANG SERUNI RS JIWA DR RADJIMAN WEDIODININGRAT LAWANG
}

\section{Effect of Therapy Group Activities Increase In Price of Self Interest Clients In The Soul Dr Seruni Rs Radjiman Wediodiningrat Lawang}

\author{
Sri Widowati ${ }^{1}$, Nur Lailatul $\mathbf{M}^{2}$, Widayanti ${ }^{3}$ \\ ${ }^{1,2)}$ Program Studi Ilmu Keperawatan Fakultas Ilmu Kesehatan Universitas Muhammadiyah Malang \\ ${ }^{3)}$ Alumni Mahasiswa Program Studi Diploma III Keperawatan Fakultas Ilmu Kesehatan Universitas \\ Muhammadiyah Malang \\ Jl. Bendungan Sutami 188A Malang 65145 \\ "e-mail: irs_widowati27@yahoo.co.id
}

\begin{abstract}
ABSTRAK
KSalah satu terapi modalitas adalah Terapi Aktivitas Kelompok (TAK) yang ditujukan untuk klien dengan masalah yang sama. TAK merupakan salah satu cara yang digunakan untuk meningkatkan harga diri pasien agar dapat kembali ke masyarakat sehingga dapat berinteraksi dengan orang lain dan lingkungan sekitarnya. Untuk pasien menarik diri kita dapat melakukan dengan TAK peningkatan harga diri yang bertujuan untuk menerima dirinya sendiri dengan penuh kepercayaan, menghargai dirinya, dan menilai positif diri sendiri. TAK peningkatan harga diri merupakan upaya untuk meningkatkan harga dirinya bagi pasien menarik diri yang harga dirinya rendah. Tujuannya mengidentifikasi ada tidaknya pengaruh TAK peningkatan harga diri terhadap harga diri pasien menarik diri. Desain penelitian menggunakan preexperiment design dengan pendekatan pre test-post test design. Menggunakan purposive sampling sebanyak 5 responden. Alat pengumpulan data yang digunakan adalah lembar observasi dengan menggunakan uji wilcoxon signed ranks test. Penelitian dilaksanakan selama sebulan pada bulan Juli 2009 di Ruang Seruni. Dari hasil analisa data dan interpretasi data dapat disimpulkan, harga diri pada pasien menarik diri sebelum diberikan TAK peningkatan harga diri mean untuk pre test $=11,8000$ dan setelah dilakukan TAK peningkatan harga diri mengalami penurunan tanda gejala harga diri rendah mean untuk post test $=4,2000$. Dan didapatkan perhitungan menggunakan uji wilcoxon signed ranks test adalah $\mathrm{z}=-5^{\mathrm{a}}$ dan $\mathrm{p}=0,00(\mathrm{p}<0,05)$. Sehingga Ho ditolak, artinya ada pengaruh yang signifikan antara sebelum dan setelah dilakukan terapi aktivitas kelompok peningkatan harga pada pasien menarik diri di RS Jiwa DR Radjiman Wediodiningrat Lawang.
\end{abstract}

Kata kunci: TAK peningkatan harga diri, peningkatan harga diri, menarik diri

\section{ABSTRACT}

One of modality therapy is group activity therapy addressed for client with the same problem. Group activity therapy be one of way applied to increase patient self-regard to regain to public causing interaction can with others and vicinity area. For patient withdraws we can do with group activity therapy of increase of self-regard with aim to receive their/his self fully trust, esteems self, and assess positive of own self. Group activity therapy of increase of self-regard is striving to increase the price of self for patient withdraws which the price of low self. As for purpose of generally is identify there are not of increase group activity therapy influence of self-regard to increase of self-regard at patient withdraws. Research design applied is research design of pre method pre-experiment design with approach of pre test-post test design. Sample taken is purposive sampling counted five responders. Data collecting method applied is observation sheet by using wilcoxon signed ranks test. Research executed during one month in July 2009 in chamber Seruni. From result analysis data interpretation and data can be concluded, self regard at patient withdraw before given do not the make-up of self regard of mean for the pre of test $=11,8000$ and after conducted do not the make-up of natural self regard of degradation of low self regard symptom sign of mean for the post of test $=4,2000$. And got by calculation use test of wilcoxon ranks signed test is $z=$ - $5^{a}$ and $p=0,00(p<0,05)$. So that Ho refused, mean there is influence which isn't it between before and after conducted by group activity therapy is make-up of price at patient withdraw in DR Radjiman Wediodiningrat Lawang Mental Hospital. 


\section{LATAR BELAKANG}

Gangguan kesehatan jiwa pada pasien jiwa bermacam-macam, salah satunya adalah menarik diri. Menarik diri (withdrawal) adalah suatu tindakan melepaskan diri, baik perhatian maupun minatnya terhadap lingkungan sosial secara langsung (isolasi diri). Pada mulanya klien merasa dirinya tidak berharga lagi sehingga merasa tidak aman dalam berhubungan dengan orang lain. Pada klien dengan menarik diri diperlukan rangsangan atau stimulus yang adekuat untuk memulihkan keadaan yang stabil. Stimulus yang positif dan terus menerus dapat dilakukan oleh perawat. Apabila stimulus tidak dilakukan atau diberikan kepada klien tetap menarik diri yang akhirnya dapat mengalami halusinasi, kebersihan diri kurang dan kegiatan hidup sehari-hari kurang adequat. Klien menarik diri juga mengalami penurunan harga diri karena kurangnya kepercayaan diri.

WHO (2001) menyatakan, paling tidak ada satu dari empat orang di dunia mengalami masalah mental. WHO memperkirakan ada sekitar 450 juta orang di dunia yang mengalami gangguan kesehatan jiwa (Yosep, 2007). Penelitian oleh FIKUI pada 2000 tentang pengaruh model TAK sosialisasi terhadap kemampuan komunikasi verbal dan non verbal pada klien menarik diri di rumah sakit jiwa. Sampel sebanyak 36 klien menarik diri di RSJP Jakarta dan 76 klien di RSJP Bogor. Hasil penelitian menunjukkan bila dibandingkan dengan standar kemampuan yang diharapkan yaitu $75 \%$, maka kemampuan kelompok intervensi melebihi standart sedang kelompok non intervensi kurang dari standar tersebut. Perbandingan kenaikan kemampuan komunikasi antara kelompok intervensi TAKS dan non TAKS berbeda bermakna dengan $p=0,0001$. Hasil survey peneliti pada 14 Juli 2009 di RS Jiwa DR Radjiman Wediodiningrat Lawang di
Ruang Seruni dengan prosentase menarik diri lebih tinggi yaitu $36,36 \%$ (8 orang).

Harga diri merupakan katalisator untuk mempertahankan cahaya batin yang dapat menciptakan kondisi lingkungan eksternal yang kondusif bagi pengembangan pribadi. Melalui harga diri inilah kita dapat membedakan diri dengan orang lain dengan kata lain harga diri digunakan sebagai parameter untuk menilai atau membedakan diri kita dengan orang lain dalam hal penghargaan terhadap keunikan penampilan fisik, kemampuan intelektual, kecakapan pribadi, dan kepribadian. Harga diri yang positif dapat meningkatkan kesadaran akan perkembangan diri atau kapan tindakan dan pikiran melenceng dari tujuan semula, sehingga dapat menghadapi tantangantantangan bila diperlukan (Malieq, 2007).

Pasien menarik diri perlu mendapatkan perhatian khusus untuk dapat kembali ke masyarakat dengan memiliki konsep diri yang positif sehingga dapat memudahkan mereka untuk bersosialisasi kepada orang lain dengan meningkatkan harga diri mereka terlebih dahulu. Salah satu upaya untuk dapat mengembalikan harga diri klien menarik diri dengan memberikan terapi modalitas yaitu terapi aktivitas kelompok (Keliat, 2004).

\section{METODE}

Penelitian ini merupakan pre experiment dengan menggunakan pre test-post test design. Responden sebanyak 5 orang dengan karakteristik: bersedia mengikuti TAK peningkatan harga diri; klien menarik diri tidak dalam fase krisis; klien tidak dalam keadaan sakit fisik.

Penelitian dilakukan di Ruang Seruni RS Jiwa DR Radjiman Wediyodiningrat Lawang selama 1 bulan pada bulan Juli 2009. Dengan menggunakan purposive sampling, klien dengan menarik diri diberi pre test (observasi) tentang peningkatan harga diri, kemudian 
diberi perlakuan berupa TAK peningkatan harga diri sebanyak 5 kali selama 20 menit dan dilakukan post test (observasi). Selama observasi menggunakan instrument berupa lembar observasi, dan panduan pengamatan. Data hasil observasi dianalisa menggunakan uji wilcoxon signed ranks test dengan program SPSS 10 for windows dengan nilai signifikansi (kesalahan) adalah á $<0,05$.

\section{HASIL DAN PEMBAHASAN}

\section{Harga Diri Klien Menarik Diri (Pre Test)}

Dari tabel 1 diketahui pada mean untuk pre test $=11,8000$ hal ini menunjukkan harga diri klien menarik diri sebelum dilakukan TAK peningkatan harga diri (pre test) masih rendah.

\section{Harga Diri Klien Menarik Diri (Post Test)}

Dari tabel 2 diketahui pada mean untuk post test $=4.2000$ hal ini menunjukkan harga diri klien menarik diri sesudah dilakukan TAK peningkatan harga diri (post test) mengalami peningkatan.

\section{Pengaruh TAK Peningkatan Harga Diri Terhadap Harga Diri Klien Menarik Diri.}

Dari tabel 3 diketahui hasil yang diperoleh dari perhitungan menggunakan uji wilcoxon signed ranks test adalah $\mathrm{z}=-5^{\mathrm{a}}$ dan $\mathrm{p}=0,00(\mathrm{p}<0,05)$. Sehingga Ho ditolak, artinya ada pengaruh yang signifikan antara sebelum dan setelah dilakukan terapi aktivitas kelompok peningkatan harga.

\section{Harga Diri Klien Menarik Diri (Pre Test)}

Sebelum dilakukan terapi aktivitas kelompok peningkatan harga diri masingmasing responden dilakukan pre test terlebih dahulu dengan menggunakan lembar observasi. Sehingga dapat disimpulkan bahwa dari hasil observasi yang dilakukan diketahui semua responden pada penelitian ini merupakan klien menarik diri yang mempunyai tanda gejala dengan harga diri rendah yang belum pernah dilakukan terapi aktivitas kelompok peningkatan harga diri, dan selain itu juga klien mengalami penurunan harga diri.

Hal tersebut sesuai dengan teori yang menyatakan harga diri rendah dapat digambarkan sebagai perasaan yang negatif terhadap diri sendiri, hilang kepercayaan, dan merasa gagal dalam mencapai keinginan (Keliat, 2002).

\section{Harga Diri Klien Menarik Diri (Post test)}

Setelah dilakukan terapi aktivitas kelompok peningkatan harga diri tampak adanya perubahan nilai dari responden. Sehingga seluruh responden mengalami peningkatan harga diri ditandai dengan berkurangnya tanda dan gejala harga diri rendah pada klien menarik diri. Terdapat 2 responden yang mengalami penurunan tanda gejala karena responden tersebut dikategorikan dalam fase pemeliharaan, 1 responden mengalami penurunan tanda gejala dan masuk dalam fase pemeliharaan, dan 2 responden mengalami penurunan tanda gejala karena masuk dalam fase akut. Sehingga setelah dilakukan terapi aktivitas kelompok peningkatan harga diri tidak ada lagi responden yang mengalami penurunan tanda gejala, bahkan sebaliknya semua responden mengalami peningkatan terhadap harga dirinya. Hal ini dikarenakan semua responden tidak dalam fase krisis, semua responden mengikuti tiap-tiap tahap terapi aktivitas kelompok dengan baik, tidak meninggalkan tempat saat melakukan terapi aktivitas kelompok peningkatan harga diri. 
Tabel 1. Identifikasi harga diri klien menarik diri sebelum dilakukan TAK peningkatan harga diri (pre test)

\begin{tabular}{lrrrrr}
\hline & $\mathrm{N}$ & \multicolumn{1}{c}{ Mean } & \multicolumn{1}{c}{ Std. deviation } & \multicolumn{1}{c}{ Min } & \multicolumn{1}{c}{ Max } \\
\hline Pre test & 5 & 11.8000 & .44721 & 11.00 & 12.00 \\
Post tes & 5 & 4.2000 & 2.58844 & 2.00 & 7.00 \\
\hline
\end{tabular}

Tabel 2. Identifikasi harga diri klien menarik diri setelah dilakukan TAK peningkatan harga diri (post test)

\begin{tabular}{lrrrrr}
\hline & $\mathrm{N}$ & \multicolumn{1}{c}{ Mean } & \multicolumn{1}{c}{ Std. deviation } & \multicolumn{1}{c}{ Min } & \multicolumn{1}{c}{ Max } \\
\hline Pre test & 5 & 11.8000 & .44721 & 11.00 & 12.00 \\
Post tes & 5 & 4.2000 & 2.58844 & 2.00 & 7.00 \\
\hline
\end{tabular}

Tabel 3. Pengaruh TAK peningkatan harga diri terhadap harga diri klien menarik diri

\begin{tabular}{lllcc}
\hline & $\mathrm{N}$ & Mean rank & Sum of ranks \\
\hline Pre test-Post tes & Negative ranks & $5^{\mathrm{a}}$ & 3.00 & 15.00 \\
& Positive ranks & $0^{\mathrm{b}}$ & .00 & .00 \\
& Ties & $0^{\mathrm{c}}$ & & \\
& Total & 5 & & \\
\hline
\end{tabular}

Adanya kiat-kiat pengembangan harga diri pada klien yang mengalami penurunan harga diri seperti: melihat diri sendiri sebagai pribadi yang terpisah dari serangkaian nilai, kebutuhan, dan impian yang anda miliki; melatih pikiran untuk menghargai diri sendiri sebagaimana adanya; hentikan kebiasaan merendahkan diri dengan mengubah self-talk; menjadi diri yang "sebenarnya"; dan hentikan sikap mengalahkan diri sendiri. Kiatkiat tersebut akan mengembalikan konsep diri klien menjadi lebih adaptif.

\section{Pengaruh TAK Peningkatan Harga Diri Terhadap Harga Diri Klien Menarik Diri}

Masing-masing responden mengalami peningkatan harga diri ditandai dengan berkurangnya tanda gejala yang dimiliki.

Dari hasil uji analisa menunjukan bahwa terapi aktivitas kelompok peningkatan harga diri memberikan pengaruh positif terhadap harga diri klien menarik diri sehingga dapat memudahkan klien untuk bersosialisasi baik di lingkungan rumah sakit maupun di rumah.

Hal ini sesuai dengan tujuan terapi aktivitas kelompok yaitu berfokus pada peningkatan harga diri dengan klien dengan gangguan persepsi, menarik diri dengan realita, inisiatif dan kurang ide, kooperatif, sehat fisik, dan dapat berkomunikasi verbal (Yosep, 2007). Selain itu, fokus terapi aktivitas kelompok peningkatan harga diri adalah untuk meningkatkan harga diri yang ditandai dengan mengenali diri sendiri, menghargai diri sendiri, tidak memusuhi diri sendiri dan berfikir positif dan rasional. Selain itu terapi aktivitas kelompok memiliki manfaat yaitu: mendapat informasi harapan anggota kelompok, meningkatkan harapan anggota kelompok, memberikan kesadaran tentang adanya persamaan pikiran, perasaan, dan masalah. Berbagai masalah pengalaman untuk menolong orang lain, membantu pengalaman belajar yang sebelumnya didapat dalam keluarga, kesempatan untuk meningkatkan kemampuan atau keterampilan melalui perilaku imitasi pada anggota kelompok, kesempatan untuk meningkatkan kewaspadaan terhadap interaksi sosial dan keterampilan sosial, meningkatkan kemampuan hubungan yang luas, sehingga tanggung jawab dan kompleksitas dalam berhubungan meningkat. Meningkatkan kemampuan anggota untuk menggali eksistensi mereka, dan kesempatan untuk mengekspresikan perasaan yang tidak terekspresikan (Yalon dalam Stuard \& Sundeen, 1995). 


\section{KESIMPULAN DAN SARAN}

Berdasarkan pembahasan disimpulkan bahwa sebelum dilakukan terapi aktivitas kelompok peningkatan harga diri klien menarik diri, seluruh responden belum menunjukkan adanya perubahan pada harga dirinya dikarenakan seluruh responden masih memiliki tanda gejala harga diri rendah. Setelah dilakukan terapi aktivitas kelompok peningkatan harga diri pada klien menarik diri, responden mengalami perubahan yang bermakna yang ditandai dengan berkurangnya tanda gejala harga diri rendah. Ada pengaruh terapi aktivitas kelompok peningkatan harga diri terhadap harga diri klien menarik diri.

Saran yang dapat diberikan kepada peneliti selanjutnya dalam melakukan penelitian sebaiknya dengan menggunakan responden yang lebih banyak, dan terapi aktivitas kelompok peningatan harga diri ini sebaiknya masing-masing tahap tidak hanya dilakukan sekali, melainkan lebih dari satu kali. Disarankan juga melakukan penelitian dalam jangka waktu yang cukup lama, karena terapi ini membutuhkan observasi lebih lanjut dalam memantau munculnya kekambuhan pada klien.

\section{DAFTAR PUSTAKA}

Anonymus. 2002. Pelatihan Nasional Asuhan Keperawatan Profesional Jiwa dan Komunikasi Terapeutik Keperawatan. Makalah tidak dipublikasikan. Malang: Tim PPNI RS Jiwa DR Radjiman Wediodiningrat.

DepKes RI. 2000. Buku Pedoman Asuhan Keperawatan Jiwa I: Keperawatan Jiwa Teori dan Tindakan Keperawatan. Jakarta.

Keliat, B.A. 2004. Keperawatan Jiwa: Terapi Aktivitas Kelompok. Jakarta: EGC.

Malieq. 2007. http://malieq.wordpress.com / 2007/08/25/5-kiat-mengembangkan- harga-diri-yang-rendah/. Diakses pada 21 Desember 2008.

Mansjoer, A. 2000. Kapita Selekta Kedokteran. Jakarta: Media Aeskulapius.

Maramis, W.F. 1998. Catatan Ilmu kedokteran Jiwa. Surabaya: Airlangga university Press.

Stuart. 2007. Buku Saku Keperawatan Jiwa. Edisi 5. Jakarta: EGC.

Stuart, G.W., Sundeen, S.J. 1995. Principles and Practice, psychiatric Nursing. 5th edition. Lippicoln: Philadhelpia.

Yosep, I. 2007. Keperawatan Jiwa. Ed. 1. Bandung: PT Refika Aditama. 